\title{
Isothermal seed germination of Adenanthera pavonina
}

\author{
FRANCISCO ANTONIO ZPEVAK ${ }^{1,3}$, SÔNIA CRISTINA JULIANO GÜALTIERI DE ANDRADE \\ PEREZ ${ }^{2}$ and MARCOS SILVEIRA BUCKERIDGE ${ }^{3}$
}

(received: November 05, 2012; accepted: November 26, 2012)

\begin{abstract}
Isothermal seed germination of Adenanthera pavonina). This work reports aspects of seed germination at different temperatures of Adenanthera pavonina L., a woody Southeast Asian Leguminosae. Germination was studied by measuring the final percentages, the rate, the rate variance and the synchronisation of the individual seeds calculated by the minimal informational entropy of frequencies distribution of seed germination. Overlapping the germinability range with the range for the highest values of germination rates and the minimal informational entropy of frequencies distribution of seed germination, we found that the best temperature for the germination of $A$. pavonina seeds is $35^{\circ} \mathrm{C}$. The slope $\mu$ of the Arrhenius plot of the germination rates is positive for $\mathrm{T}<35^{\circ} \mathrm{C}$ and negative for $\mathrm{T}>35^{\circ} \mathrm{C}$. The activation enthalpies, estimated from closely-spaced points, shows that $|\Delta H-|<12 \mathrm{Cal} \mathrm{mol}^{-1}$ occur for temperatures in the range between $25^{\circ} \mathrm{C}$ and $40^{\circ} \mathrm{C}$. The ecological implication of these results are that this species may germinate very fast in tropical areas during the summer season. This may be an advantage to the establishment of this species under the climatic conditions in those areas.
\end{abstract}

Key words - Leguminosae, synchronisation, temperature, thermobiology

\section{INTRODUCTION}

Adenanthera pavonina L. is a woody Southeast Asian species of Leguminosae-Mimosoideae. It belongs to wild underexploited leguminous crop seeds and may be a potential source of feed for livestock and industrial uses (Balogun \& Fetuga 1986). The present study was initiated in order to define the germination requirements of this species at different temperatures.

The temperature is the main environmental factor governing the germination of seeds because it strongly influences physiological and biochemical processes (Egley 1995, Cardoso 2009). The temperature dependence of seed germination may be described by several parameters: the minimal cardinal point, below which it is not measurable; the maximum cardinal point, above which it is not measurable; and the optimum temperature interval at which the germinability is consistently kept at a uniform level and the germination proceeds at the highest rate (Labouriau 1983).

The extreme temperature limits of seed germination are easily determined empirically and provide information of biogeografical and ecological interest (Thompson

\footnotetext{
1. Universidade Federal de São Carlos, Centro de Ciências Biológicas e da Saúde, Programa de Pós-Graduação em Ecologia e Recursos Naturais, Rodovia Washington Luiz km 235, 13565-905 São Carlos, SP, Brazil.

2. Universidade Federal de São Carlos, Centro de Ciências Biológicas e da Saúde, Departamento de Botânica, Rodovia Washington Luiz km 235, Caixa Postal 676, 13565-905 São Carlos, SP, Brazil.

3. Universidade de São Paulo, Instituto de Biociências, Departamento de Botânica, Rua do Matão 277, 05508-090 Cidade Universitária, São Paulo, SP, Brazil.

4. Corresponding author: msbuck@usp.br
}

1973, Dau \& Labouriau 1974). They also reflect the physiological and morphological features of the seeds prior to germination, since they can be altered by specific treatments before the germination tests (Vegis 1963). Santos \& Cardoso (2001), for instance, found that seed coat cane interfere with the themal responses related to seed germination of Cucumis anguria.

The rates of seed germination generally increase as the temperature is raised from near $0{ }^{\circ} \mathrm{C}$ and become maximal in the range of 20 to $35^{\circ} \mathrm{C}$ depending on the species. With further increase in temperature the rates rapidly decrease (Labouriau 1983). This pattern of dependence on the physiological processes is common to many developmental events such as the emergence of seedlings, the appearance of a series of leaves, and flowering and it resembles the effect of temperature on enzyme activity (Kramer \& Kozlowski 1979).

The main physiological interest in studying the temperature dependence of the isothermal germination rates is the search for limiting factors and partial processes of seed germination (Labouriau 1983). In this study we examined the effects of temperature on the germination of seeds of Adenanthera pavonina by measuring the final percentages, the rate variance and the synchronisation of the individual seeds calculated by the minimal informational entropy of frequencies distribution of seed germination. The slope $\mu$ of the Arrhenius plot of the germination rates was calculated and the activation enthalpies were estimated from closely spaced points at all the temperature range. The distribution of the relative frequency of germination along the time of isothermal incubation of the seeds was considered in order to study the communication-aspect 
of thermal control of seed germination and to measure the degree of synchronisation of isothermal independent germination events (Labouriau \& Valadares 1976). The ecological implications were discussed considering that these results may give information about how to quickly obtain seedlings of this species and on the possibilities of adaptation of it in tropical areas.

\section{MATERIAL AND METHODS}

\section{Plant material}

Seeds of Adenanthera pavonina L. were harvested in Campo Grande, MS, Brazil, in March 1992. The seeds were neither sterilised nor selected. However, the occasional deformed individuals (abnomaly small, damaged or offcoloured) were discarded.

\section{Seed germination}

The isothermal incubation of seeds was performed with samples of 200 seeds, in $13 \times 2 \mathrm{~cm}$ Pyrex glass Petri dishes, lined with analytical filter paper discs and kept saturated with deionised water $\left(12.5 \mathrm{~mL} \mathrm{disc}^{-1}\right)$. Fifty seeds were placed in each plate, spaced an equal distance apart along a spiral line in order to facilitate the subsequent checking for germination under the dissecting scope. Constant temperature was assured by use of Incubators, (FANEN model 565), in which the inside air is kept thermally uniform by a fan. The precision of temperature control was within the range of $\pm 0.5^{\circ} \mathrm{C}$. Seeds were kept in the dark and considered germinated when the roots were $\geq 2 \mathrm{~mm}$ long. Germination was recorded daily and always at the same hour (2:00 P.M.), the examination being performed as quickly as possible. The germinated seeds were removed and water was replenished so that saturation of the filter paper was maintained. Temperatures used for tracing germination isotherms were $10,15,20,25,30,40$ and $45^{\circ} \mathrm{C}$.

Scarification was performed by treating the seeds with concentrated sulphuric acid during $25 \mathrm{~min}$. After this treatment, the seeds were washed thoroughly with running tap water followed by distilled water and air-dried for 24 hours prior to use. This procedure promoted uniform imbibition and germination.

The germination capacity (= germinability) was measured by the final germination percentages, G (\%), of simultaneous isothermal replicates.

The optimum range for the germinability was estimated by searching for the temperature intervals within which the germinability values were among the highest and such that there were no pairs of temperature treatments with significant difference.

The first step was the computing of descriptive statistics obtaining the following information:

(a) The average of the germination times, $\bar{t}=\Sigma n_{i} t_{i} / \Sigma n_{\mathrm{i}}$, were: $n_{i}=$ number of seeds germinated between observations $t_{i-1}$ and $t_{i}$ (Harrington 1962); (b) Their variance, $s_{t}^{2}=\Sigma n_{\mathrm{i}}(t-\bar{t})_{2} /-1+\Sigma n_{\mathrm{i}} \quad$ (Labouriau 1972, Dau \& Labouriau 1974);

(c) The average germination rate, $\bar{v}=1 / \bar{t}$ (Kotowski 1926, Labouriau 1970);

(d) The rate variance, $s_{v}^{2}=(\bar{v})_{4} \cdot s_{t}^{2}$ (Labouriau 1972b, 1983);

(e) The weighted average, $\overline{\mathrm{V}}=\Sigma w_{j} \bar{v}_{j} / \Sigma w_{j}$, with $w_{j}=n_{j} / s^{2}{ }_{j}$ were $n_{j}=$ number of germinated seeds in the $j^{\text {th }}$ replication, and $s_{j}^{2}=$ variance of the germination rate of this replication (Snedecor 1956).

This last average, $\overline{\mathrm{V}}$, is more representative than the unweighted average of simultaneous replications, since it takes into account the differences in the rate variance of the replicates.

The optimal temperature range for the germination rate was obtained by comparing the set of four rates corresponding to the replicates of each isothermal treatment with all other such sets of temperature treatments, using a one-tailed MannWhitney test. The optimal range was taken as the temperature interval within which all the rate values are at the highest level and such that there are no pairs of temperature treatments with significantly different rates (Labouriau \& Pacheco 1979).

The variation of $\mu$ was used to locate the temperature optimum, $\mathrm{T}_{0}$. In fact,

$\mu=\frac{d(-R \ln \bar{V})}{d(1 / T)}=-R \frac{d(\ln \bar{V})}{d T} \cdot \frac{d T}{d(1 / T)}=\frac{R T^{2}}{\bar{V}} \cdot \frac{d \bar{V}}{d T} \quad$ since $\frac{R T^{2}}{\bar{V}}$ is always positive, it follows that $\mu$ and $\frac{d \bar{V}}{d T}$ has necessarily the same sign. From the definition of the temperature optimum we have $\frac{d \bar{V}}{d T}>0$ for $\mathrm{T}<\mathrm{T}_{\mathrm{o}}$ and $\frac{d \bar{V}}{d T}<0$ for $\mathrm{T}>\mathrm{T}_{\mathrm{o}}$ (Labouriau 1972a).

The comparison of the optimum ranges of the germinability and of the germination rate poses the problems of the similarities and differences among their limiting factors. One of the available tools for the study of the limiting factors of the rate is its Arrhenius plot, $-R \ln \bar{V}=A(1 / T)$, with $R=1.987 \mathrm{Cal} \mathrm{mol}^{-1}$ and $T$ in Kelvin degrees, which was constructed for the weighted average rates, $\overline{\mathrm{V}}$. The slopes of the Arrhenius graph computed between two successive and close temperatures, allows an estimate of the activation enthalpies, $\Delta H^{\ddagger}[\partial(-R \ln \bar{V}) / \partial(1 / T)]_{P S}-R T$.

\section{Synchronisation of the germination}

The synchronisation was measured with the index: $\overline{\mathrm{E}}=\log _{2} N-(1 / N) \sum n_{i} \cdot \log _{2} n_{i}$, were $N$ is the total number of germinated seeds and $n_{i}$ is the number of germinated seeds between the $\left(i-1^{\text {th }}\right)$ observations, along the isothermal incubation time (Labouriau \& Valadares 1976).

The estimate of the temperature range for the synchronisation was obtained by comparing the set synchronisation corresponding to the replicates of each isothermal treatment with all other such sets of temperature treatments, using a one-tailed Mann-Whitney test. The 
optimal range was taken as the temperature interval within which all the synchronisation values are at the highest level and such that there are no pairs of temperature treatments with significantly different synchronisation.

Time distribution of germination frequencies $\left[f_{i}=\varphi_{T}\left(t_{i}\right)\right]$, were: $f_{i}=n_{i} / \Sigma n_{i}=$ relative frequency of germination, $T=$ temperature and $t_{i}=$ incubation time.

The determination of modal germination times, $t_{m o}$, allows classification of the germination isotherms into two groups, according to whether their $f_{i}=\varphi_{T}\left(t_{i}\right)$ distributions are unimodal or not. This is an assessment of the homogeneity of these seeds, for polymodal distributions clearly display subsets of seeds with different germination times clustering around successive $t_{m o}$ values. The assymmetry and the kurtosis of the $f_{i}=\varphi_{T}\left(t_{i}\right)$ distributions were measured by their 3rd and 4 th moments about the mean $\bar{t}$, respectively.

The uncertainties of such $f_{i}=\varphi_{T}\left(t_{i}\right)$ distributions were computed in bits by the well-known expression $U=-\Sigma f_{i} \cdot \log _{2} f_{i}$. The $U$-values appraise the degree of synchronisation of the germination of individual seeds (Labouriau \& Valadares 1976). On the other hand, $U$ is also an information function for the specification of seed germination by environmental temperature (Labouriau \& Valadares 1976, Labouriau 1978). In this connection, it is important to recall that, for a given variance (in this case $\sigma_{2}=s_{t}^{2} / N$ ) the Gaussian is the distribution with maximal uncertainly, $U_{\max }=\frac{1}{2} \log _{2}\left(2 \pi e s_{t}^{2} / N\right)$ (Shannon 1948), corresponding to what is usually referred to as "random thermal noise". Hence the fit of each $f_{i}=\varphi_{T}\left(t_{i}\right)$ distribution to its corresponding Gaussian (adjusted by the parameters $\mathrm{N}, \bar{t}$ and $S_{t}^{2}$ ) provides a means of analysing the pattern of thermal communication of the germinating seed. When the $f_{i}=\varphi_{T}\left(t_{i}\right)$ distributions do not fit their adjusted Gaussians, there is a temperature signal superimposed upon the background noise, whereas the adhesion of the $f_{i}=\varphi_{T}\left(t_{i}\right)$ to the adjusted normal indicates that the $T$-signal is quenched by random thermal noise (Labouriau 1978). The goodness of this fit was evaluated by the Kolmogorov-Smirnov Test (Sokal \& Rohlf 1969).

\section{Optimum range for the germination}

The optimum range for the germination was estimated by searching for the temperature intervals within which the germinatibility values are among the highest and overlap the highest average germination rates and the minimal informational entropy of frequencies distribution of seed germination values.

\section{RESULTS}

The germinability, the germination rate and the informational entropy of frequency distribution of Adenanthera pavonina seeds are shown in table 1. Data of this table show that the minimum cardinal point is between $10^{\circ} \mathrm{C}$ and $15^{\circ} \mathrm{C}$, and the maximum cardinal point lies between $40^{\circ} \mathrm{C}$ and $45^{\circ} \mathrm{C}$, i.e. there was no germination at $10^{\circ} \mathrm{C}$ or $45^{\circ} \mathrm{C}$.

As shown in table 1, the simultaneous test procedure used to find the maximum groups of isotherms within

Table 1. Results of the analysis of the germinability $(G)$, germination rate $(\bar{V})$, variances of germination rates $\left(S_{v}^{2}\right)$ and of the index of synchronization of germination rates $(\bar{E})$.

\begin{tabular}{|c|c|c|c|c|c|c|}
\hline \multirow{2}{*}{$\begin{array}{l}\text { Temperature } \\
{\left[{ }^{\circ} \mathrm{C}( \pm 0.5)\right]}\end{array}$} & \multicolumn{3}{|c|}{$\begin{array}{c}\text { Germinability }{ }^{(a)} \\
(\%)\end{array}$} & \multirow{2}{*}{$\begin{array}{c}\overline{\mathrm{V}}^{(b)} \\
\left(\mathrm{day}^{-1} 10^{2}\right)\end{array}$} & \multirow{2}{*}{$\begin{array}{c}S_{v}^{2(c)} \\
\left(\mathrm{day}^{-1} 10^{5}\right)\end{array}$} & \multirow{2}{*}{$\begin{array}{c}\bar{E}^{(d)} \\
\text { (bits) }\end{array}$} \\
\hline & $\mathrm{L}_{\mathrm{i}}$ & G & $\mathrm{L}_{\mathrm{s}}$ & & & \\
\hline 10 & 0.00 & 0 & 1.83 & & & \\
\hline 15 & 1.73 & $4 c$ & 7.76 & $7 e$ & $3 a$ & $1.00 a$ \\
\hline 20 & 84.96 & $90 a$ & 93.78 & $15 d$ & $82 a$ & $2.24 c$ \\
\hline 25 & 96.00 & $99 a$ & 100.00 & $22 c$ & $245 b$ & $1.90 \mathrm{~b}$ \\
\hline 30 & 90.97 & $95 a$ & 97.59 & $25 b$ & $235 b$ & $1.49 a b$ \\
\hline 35 & 82.50 & $88 a$ & 92.00 & $30 a$ & $369 b c$ & $1.37 a b$ \\
\hline 40 & 60.00 & $67 b$ & 73.50 & $28 a$ & $476 c$ & $1.51 a b$ \\
\hline 45 & 0.00 & 0 & 1.83 & & & \\
\hline$F$ & & $156.2 *$ & & $385.67 *$ & $33.02 *$ & - \\
\hline$H$ & & - & & - & - & $17.6^{*}$ \\
\hline
\end{tabular}

a Clopper-Pearson 95\% confidence interval of germination percentage (Documenta Geigy 1965).

b average germination rate (Kotowski 1926, Labouriau 1970).

c variance of germination rate (Labouriau \& Agudo 1987).

d informational entropy of frequencies distribution of germination (Labouriau \& Valadares 1976). F: Anova Fs among treatments.H: Kruskal-Wallis one-way analysis of variance by ranks.

* differences significant at the $5 \%$ level.a, b, c, d...: pairs followed by the same letter are significantly different at the $5 \%$ level according the Tukey's test (after ANOVA)/Mann-Whitney U-test (after K-W test). 
which differences among data are not significant at the $5 \%$ level. This indicates that the germinabilility within the range $20^{\circ} \mathrm{C} \leq T \leq 35^{\circ} \mathrm{C}$, the average germination rates within the range $35^{\circ} \mathrm{C} \leq T \leq 40{ }^{\circ} \mathrm{C}$ and the informational entropy of frequencies distribution of seed germination within the range $30^{\circ} \mathrm{C} \leq T \leq 40{ }^{\circ} \mathrm{C}$ and $15^{\circ} \mathrm{C}$ are not significantly different.

The relationship between germination rate and temperature is shown in figure 1 . The distribution of thermal germination rates from $10{ }^{\circ} \mathrm{C}$ to $35^{\circ} \mathrm{C}$ was normal and consequently a single equation of linear regression was applied to describe the influence of these temperatures on rates of all germinated seed of each replication. The linear relationship obtained between germination rates and temperature gave the equation $\overline{\mathrm{V}}=-10.63+1.21 . T$, where $T$ is the absolute temperature (Kelvin), $\overline{\mathrm{V}}$ being given in days ${ }^{-1} 10^{2}$. It was used to estimate the minimal cardinal temperature.

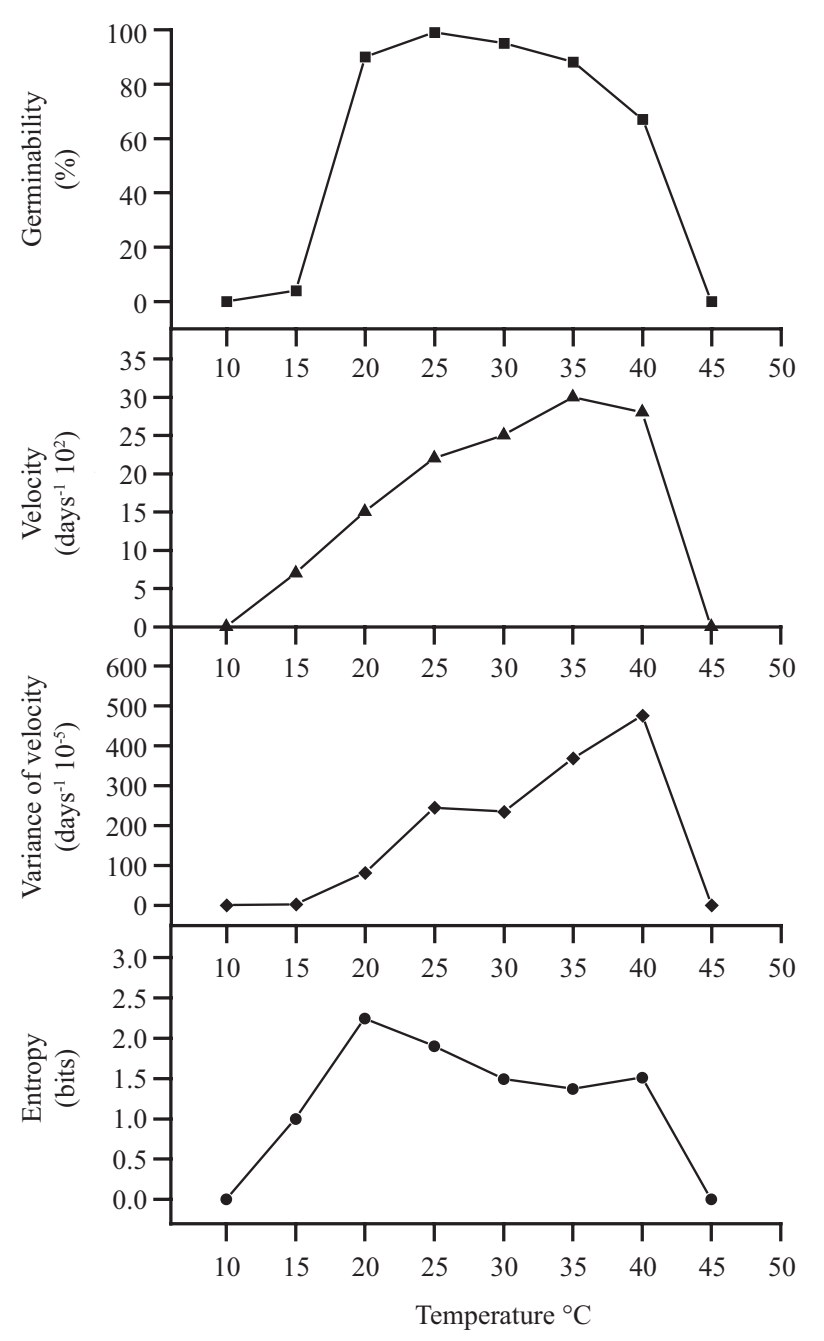

Figure 1. Effects of temperature on seed germination of Adenanthera pavonina seeds.

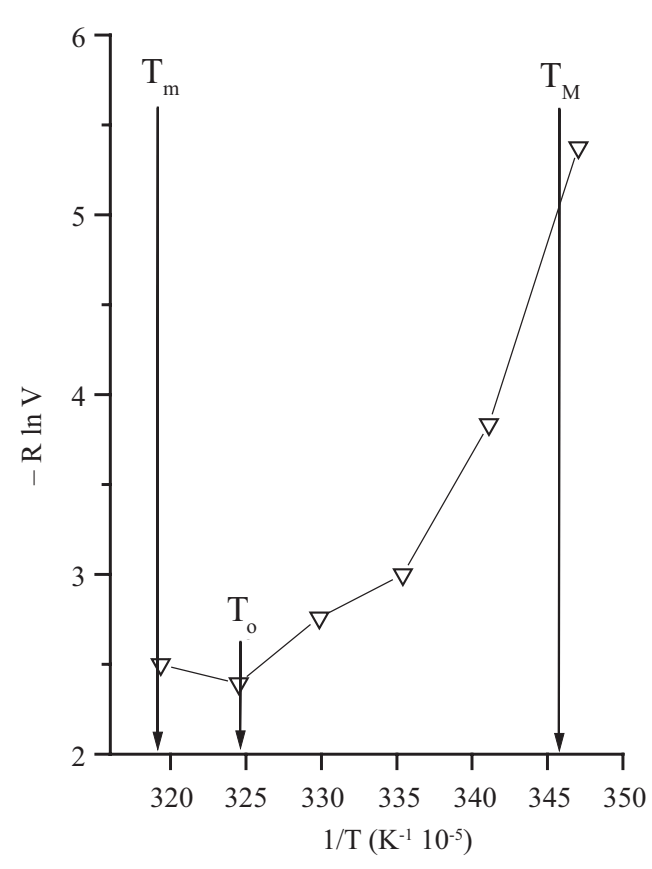

Figure 2. Temperature dependence of the average isothermal germination rate of seeds of Adenanthera pavonina $\mathrm{L}$.

As shown in the figure 2 , the intercept of the infraoptimum regression straight line that was at $9{ }^{\circ} \mathrm{C}$ differs from the experimental minimum, which is between $10^{\circ}$ and $15^{\circ} \mathrm{C}$.

The adequacy of the linear model of the temperature dependence of the germination rates for the temperature range of germination from $15{ }^{\circ} \mathrm{C}$ to $40{ }^{\circ} \mathrm{C}$ is shown in the Arrhenius' plot $-R \ln \bar{V}$ (figure 3). This Arrhenius' plot is not linear, and therefore the average isothermal germination rate of this seed does not follow Arrhenius law, the slope being itself temperature-dependent. Since the slope, $\mu$, of the Arrhenius' plot of $\bar{V}$ changes sign at opposite sides of the point corresponding to $35^{\circ} \mathrm{C}$, i.e. the slope $\mu$ is positive in the infra-optimum range and negative in the supra optimum range it follows that the temperature optimum will be $T_{o}=35^{\circ} \mathrm{C}$. The shape of the Arrhenius' plot of the germination rates show that the process of germination cannot be described as an unbranched chain of partial processes with a predominant step. On the contrary, the plot is typical of a phenomenon in which the interaction of partial process changes continuously with $T$. Nevertheless, a few general trends emerge from the consideration of the two contrasting $T$ ranges found in the Arrhenius plot. Estimates of the slopes from closely-spaced points show that $\left|\Delta H^{\ddagger}\right|>12 \mathrm{Cal} \mathrm{mol}^{-1}$ occur for $T<25^{\circ} \mathrm{C}$ and $\left|\Delta H^{\ddagger}\right|<12 \mathrm{Cal} \mathrm{mol}^{-1}$ occur for $T>25^{\circ} \mathrm{C}$ (table 2).

The variances of isothermal germination rates show increasing values between $15^{\circ}$ and $40{ }^{\circ} \mathrm{C}$ and maximum 


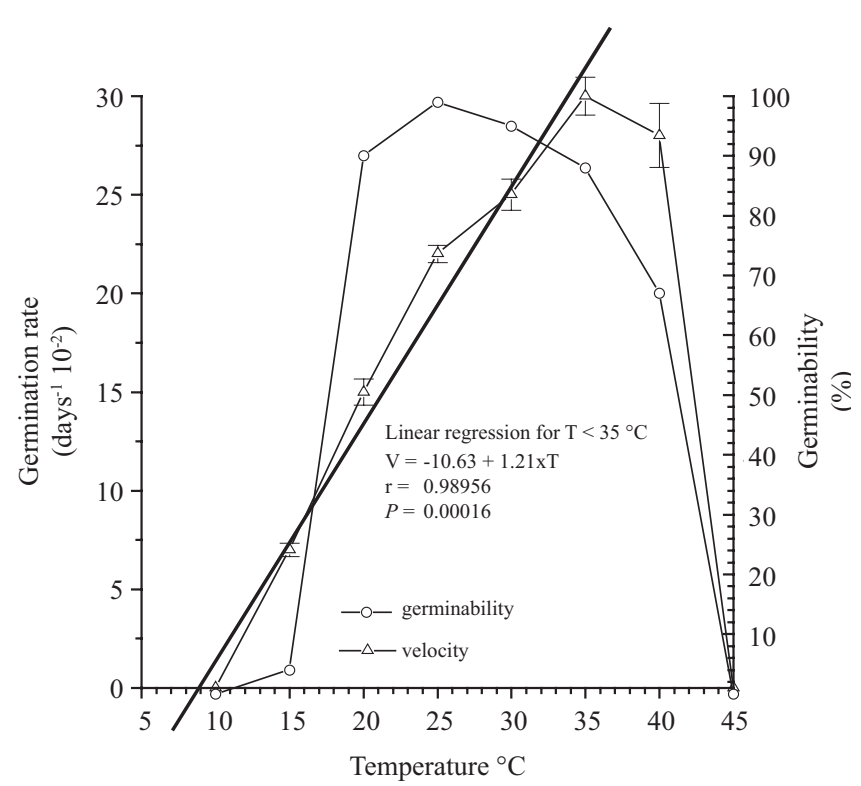

Figure 3. Arrhenius plot of the isothermal germination rates of Adenanthera pavonina seeds.

Table 2. Temperature dependence of net activation enthalpy change $\left(\overline{\Delta H^{\ddagger}}\right)$ in seeds of Adenanthera pavonina $\mathrm{L}$.

\begin{tabular}{|c|c|c|c|c|}
\hline \multicolumn{2}{|c|}{ Temperature } & \multirow{2}{*}{$\frac{\overline{\mathrm{V}}^{(\mathrm{a})}}{\left(\text { day }^{-1}\right)}$} & \multirow[t]{2}{*}{$\Delta \mathrm{T}$} & \multirow{2}{*}{$\frac{\overline{\Delta H^{\neq(b)}}}{\left(\mathrm{Cal} \mathrm{mol}{ }^{-1}\right)}$} \\
\hline$\left[{ }^{\circ} \mathrm{C}( \pm 0.5)\right]$ & {$[\mathrm{K}( \pm 0.5)]$} & & & \\
\hline 15 & 288.15 & 0.07 & & \\
\hline 20 & 293.15 & 0.15 & $15-20$ & -26.62 \\
\hline 25 & 298.15 & 0.22 & $20-25$ & -15.16 \\
\hline 30 & 303.15 & 0.24 & $25-30$ & -4.96 \\
\hline 35 & 308.15 & 0.30 & $30-35$ & -7.41 \\
\hline 40 & 313.15 & 0.28 & $35-40$ & 1.41 \\
\hline
\end{tabular}

(a) $\overline{\mathrm{V}}=\Sigma w_{j} \bar{v}_{j} / \Sigma w_{j}$ : average germination rate for pooled isothermal replications (Kotowski 1926, Labouriau 1970).

(b) $\overline{\Delta H} \neq=\frac{\Delta(-R \ln \overline{\mathrm{V}})}{\Delta(1 / T)}-R \bar{T}$ (Labouriau \& Valadares 1976).

at $40^{\circ} \mathrm{C}$, with constant germinability throughout the experimental temperature interval between $20^{\circ}$ and $35^{\circ} \mathrm{C}$ (table 1).

Average values of $\Delta H$, estimated for the experimental temperature intervals, show that the activation of germination is endothermic up to $35^{\circ} \mathrm{C}$, with a reversal of the sign $\Delta H$ at $35^{\circ} \mathrm{C}$ (table 2). These results can be understood considering that temperature exerts effect on reaction rates and changes the physical state of the cellular components.

The graphs in figure 4 show the frequency polygons obtained for pooled isothermal data of six different temperatures. There are considerable differences in the chronological distribution of germination frequencies.

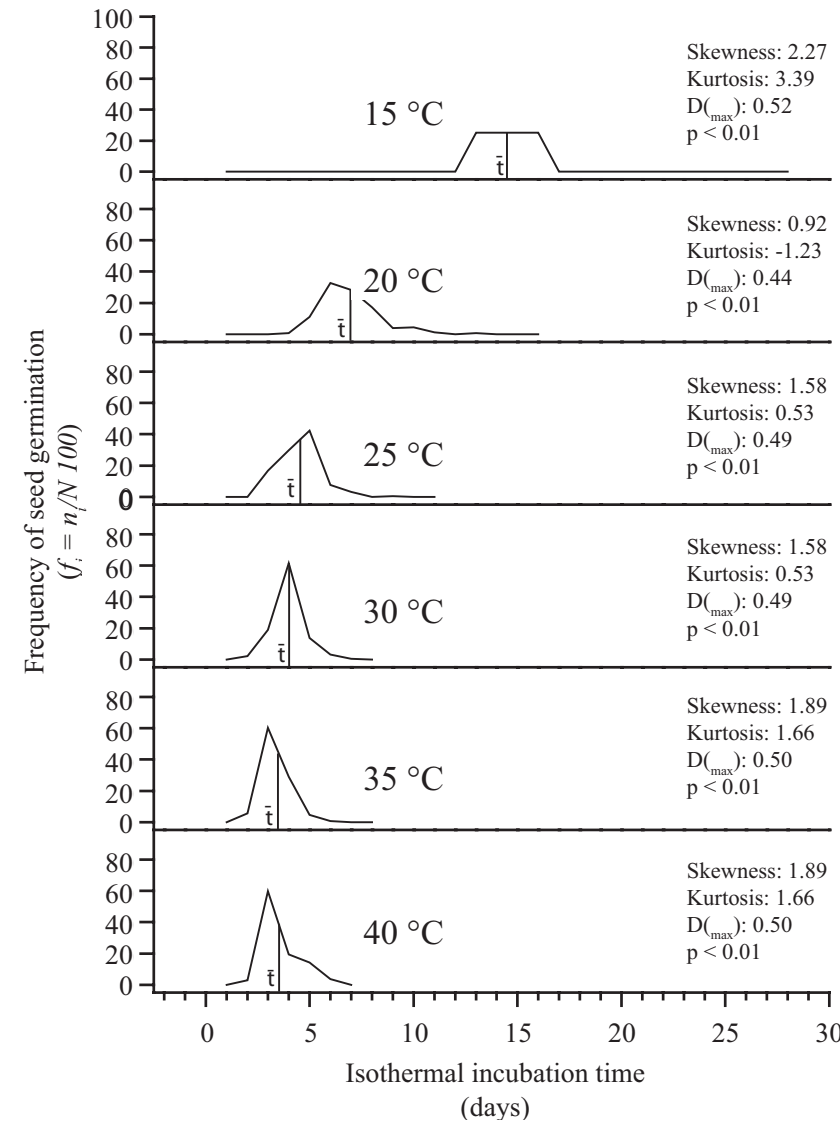

Figure 4. Relative frequencies of germination as functions of the time of isothermal incubation of the seeds of Adenanthera pavonina $\mathrm{L}$.

Such isothermal patterns differ as to the position of the modes. It is apparent that all isotherms from $20^{\circ}$ to $40^{\circ} \mathrm{C}$ give unimodal graphs. There are displacements of the modal times, $t_{m o}$, to the left from $15^{\circ}$ to $35^{\circ} \mathrm{C}$ and to the right at $40^{\circ} \mathrm{C}$. These differences indicate a temperature-specification of embryo growth in this seed. Also the displacement of the average germination time, $\bar{t}$, relative to the modal time, $t_{m o}$, is very clear from $20^{\circ}$ to $40^{\circ} \mathrm{C}$ (with the exception of the isotherm of $30^{\circ} \mathrm{C}$ ). It may also be seen in figure 4 that $\bar{t}$ is located to the right of the mode: $\bar{t}>t_{m o}$ at $20^{\circ}, 35^{\circ}$ and $40^{\circ} \mathrm{C}$. Hence, the skewness is always positive, i.e., the tails of the distributions are always to the right of the main peak. It shows that at all temperatures the heterogeneity of the seeds as to their germination rates is caused by a minority of slower germinating seeds and not by a few faster germinating seeds. The isothermal distributions graphed in figure 4 were compared with the corresponding adjusted normal distributions, using the Kolmogorov-Smirnov test. The data on the graphs, at the right, show that none of the distributions fit the adjusted Gaussians. 


\section{DISCUSSION}

The optimum of temperature for seed germination of Adenanthera pavonina can be compared to several tropical species, such as Stryphnodendron barbadetiman (Vell.) Mat. which germinates in the range between $20^{\circ} \mathrm{C}$ and $38^{\circ} \mathrm{C}$ (Barradas \& Handro 1974); Calotropis procera (Ait) Ait. F., between $18{ }^{\circ} \mathrm{C}$ and $37^{\circ} \mathrm{C}$ (Labouriau \& Valadares 1976); Kielmeyera coriaceae Mart., between $15{ }^{\circ} \mathrm{C}$ and $35^{\circ} \mathrm{C}$ (Dionello 1978); Magonia pubescens St. Hil. which has the minimum between $5{ }^{\circ} \mathrm{C}$ and $10^{\circ} \mathrm{C}$ and the maximum between $40^{\circ} \mathrm{C}$ and $45^{\circ} \mathrm{C}$ (Joly et al. 1980); Tagetes minuta L. between $10{ }^{\circ} \mathrm{C}$ and $35^{\circ} \mathrm{C}$ (Forsyth \& Staden 1983); Simmondsia chinensis (Link) Schneider between $10{ }^{\circ} \mathrm{C}$ and $40{ }^{\circ} \mathrm{C}$ (Figueiredo 1989); Dimorphandra mollis Benth. which has the minimum between $9{ }^{\circ} \mathrm{C}$ and $12^{\circ} \mathrm{C}$ and the maximum between $39^{\circ} \mathrm{C}$ and $42{ }^{\circ} \mathrm{C}$ (Zpevak 1995); Stryphnodendron polyphyllum which has the minimum between $5{ }^{\circ} \mathrm{C}$ and $10{ }^{\circ} \mathrm{C}$ and the maximum between $40{ }^{\circ} \mathrm{C}$ and $45^{\circ} \mathrm{C}$ (Tambelini 1999); Leucaena leucocephala (Lam.) de Wit with the minimum between 10 and $15{ }^{\circ} \mathrm{C}$ and the maximum between 40 and $45^{\circ} \mathrm{C}$ (Cavalcante 1995); Pterogyne nitens Tull. with the minimum between 9 and $12{ }^{\circ} \mathrm{C}$ and the maximum between 42 and $45^{\circ} \mathrm{C}$ (Nassif 1996) and Peltophrum dubium Spreng Taubert with the minimum between 6 and $9{ }^{\circ} \mathrm{C}$ maximum between 36 and $39{ }^{\circ} \mathrm{C}$ (Perez et al. 1998).

Following the criterion of measuring seed physiological homogeneity by the relative width of the temperature interval of maximum and consistent germination capacity, seeds of Adenanthera pavonina are found to be a sort of borderline case; their germinability is $\geq 88 \%$ in about $66 \%$ under $\left(20^{\circ} \mathrm{C}-35^{\circ} \mathrm{C}\right)$ of the overall temperature range of germination $\left(15^{\circ} \mathrm{C}-40{ }^{\circ} \mathrm{C}\right)$. This optimum range of seed germination is shown by other tropical species: Dipterix alata Vog. which has his optimum between $30^{\circ} \mathrm{C}$ and $36^{\circ} \mathrm{C}$ (Melhem 1975), Rapanea guianensis Aubl. between $15{ }^{\circ} \mathrm{C}$ and $35^{\circ} \mathrm{C}$ (Joly \& Felippe 1979), Magonia pubescens St. Hil. between $25{ }^{\circ} \mathrm{C}$ and $30^{\circ} \mathrm{C}$ (Joly et al. 1980), Stryphnodendron polyphyllum Mart. between $25^{\circ} \mathrm{C}$ and $30^{\circ} \mathrm{C}$ (Tambelini 1999), Leucaena leucocephala (Lam.) de Wit. with the optimum between 30 and $35^{\circ} \mathrm{C}$ (Cavalcante 1995), Pterogyne nitens Tull. with the optimum at $27^{\circ} \mathrm{C}$ (Nassif 1996) and Peltophrum dubium Spreng Taubert with the optimum between $27^{\circ} \mathrm{C}$ and $30^{\circ} \mathrm{C}$ (Perez et al. 1998).

According Hendricks \& Taylorson (1979), the temperature range between $20^{\circ} \mathrm{C}$ and $30^{\circ} \mathrm{C}$ is the most adequate to seed germination, as well as to the growth, flowering and others aspects of the plant development. Temperatures between $20^{\circ} \mathrm{C}$ and $30^{\circ} \mathrm{C}$, for example, appear to offer a favourable environment for seedling development of Tagetes minuta L. a species native of South America (Forsyth \& Staden 1983).

The germination rate usually increases linearly with temperature within the suboptimal temperature range (Hegarty 1973, Bierhuizen \& Wagenvoort 1974, Dau \& Labouriau 1974, Thompson \& Fox 1976, Whashitani $\&$ Takenaka 1984, Perez \& Moraes 1990). As shown in the figure 2 , up to $35{ }^{\circ} \mathrm{C}$ the germination rates increased linearly with temperature, the intercept is at $9{ }^{\circ} \mathrm{C}$ which differs from the experimental minimum that is between $10^{\circ}$ and $15^{\circ} \mathrm{C}$. Thus, in this case, the linear model does not give a good description of the data of pooled isothermal samples, and is not adequate to estimate the theoretical minimal cardinal temperature but show that there was a linear relationship between germination rates and temperature from $10^{\circ} \mathrm{C}$ to $35^{\circ} \mathrm{C}$.

The shape of the Arrhenius' plot of the germination rates shows that the process of germination cannot be described as an unbranched chain of partial processes with a predominant step. On the contrary, the plot shown is typical of a phenomenon in which the interaction of partial process changes continuously with temperature. Nevertheless, a few general trends emerge from the consideration of the two contrasting temperature ranges found in the Arrhenius' graph indicating that temperatures below $25^{\circ} \mathrm{C}$ can retard the metabolic rate to the point where pathways essential for the onset of germination would cease to operate, thus high levels of energy are necessary to trigger the germination; and that above $25{ }^{\circ} \mathrm{C}$ the process of germination is limited by diffusion phenomena which takes place at $\left|\Delta H^{\ddagger}\right|<12 \mathrm{Cal} \mathrm{mol}^{-1}$ (Glasstone et al. 1941).

According to the variances of isothermal germination rates showed in table 1, the maximum uncertainty about average rate values is reached at the same temperature where higher rate-values are found. Therefore, following the considerations discussed by Labouriau \& Valadares (1976), the thermodynamic entropy of the seed must increase from $20^{\circ}$ up to $40^{\circ} \mathrm{C}$ and the entropy-change upon germination is necessarily positive at $40{ }^{\circ} \mathrm{C}$. It can therefore be concluded that germination at the rate-level optimum involves a loss of order.

Average values of $\Delta H$ (table 2), can be understood considering that temperature exert an effect on reaction rates and change the physical state of the cellular components. Thus, within temperatures between $40{ }^{\circ} \mathrm{C}$ and $45^{\circ} \mathrm{C}$ the $\Delta H^{\prime}$ values must be the higher and at 
this temperatures the effects must be lethal to the seeds. These temperatures can denature seed proteins and cause membrane phase changes. The changes in permeability are related with the amino acid leakage at high temperatures (Hendricks \& Taylorson 1976).

Seeds of Zea mays L., for example, did not germinate at $41{ }^{\circ} \mathrm{C}$ but did show a raised respiration rate and increased mitochondrial efficiency in common with those incubated at $28^{\circ} \mathrm{C}$, which did germinate. The high levels of ATP at $41{ }^{\circ} \mathrm{C}$ indicated that failure to germinate was not a result of disruption of energy metabolism. However, increases in specific activities of several enzymes involved in mobilisation of embryo reserves and synthesis of new cellular materials were found in seeds imbibing at $28^{\circ} \mathrm{C}$. No such changes were found in those imbibing at $41^{\circ} \mathrm{C}$ and according Riley (1981) there is the possibility of a lower rate of protein synthesis at high temperatures. Thus, according Riley (1981) at high temperatures some of the reactions which would normally culminate in radicle protrusion proceed normally, but further development is prevented because of loss of an essential process or component particularly temperature sensitive. Is thought that the primary site of high temperature in germinating seeds is closely related with the synthesis of proteins by the embryo.

The non-Gaussian character of the isothermal distributions shown in figure 4 were previously found for other seeds (Labouriau \& Valadares 1976, Labouriau $\&$ Pacheco 1978). Considering that the onset of the germination of Adenanthera pavonina seeds must be linked to environmental exchanges of energy triggering the process of germination, these results substantiate the conclusion that the thermal communication between the environment and the seed growth-effector does not take place through random thermal noise and that there are superimposed temperature signals triggering the overall process of germination of this seeds. In fact, the germinability, the germination rate and the synchronisation of germination of the Adenanthera pavonina seeds are strongly temperature-dependent (table 1 and figure 1).

Overlapping the germinability range, with the range for the highest values of germination rates and the minimal informational entropy of frequency distribution of seed germination, we found that the best temperature for the germination of seeds of Adenanthera pavonina is $35^{\circ} \mathrm{C}$.

The ecological implication of these results are that this species may germinate very fast in tropical areas where the temperatures are between $25^{\circ} \mathrm{C}$ and $40{ }^{\circ} \mathrm{C}$ during the summer season which may be an advantage to the establishment of this species under the climatic conditions in those areas.

Acknowledgements - The authors wish to acknowledge the Conselho Nacional de Desenvolvimento Científico e Tecnológico $(\mathrm{CNPq})$ for the scholarships and other resources.

\section{REFERENCES}

Balogun AM, Fetuga BL. 1986. Chemical composition of some underexploited leguminous crop seeds in Nigeria. Journal of Food Chemistry 34:189-192.

Barradas MM, Handro W. 1974. Algumas observações sobre a germinação das sementes de barbatimão, Stryphnodendron barbadetiman (Vell.) Mart. (Leguminosae-Mimosoideae). Boletim de Botânica 2:139-150.

Bierhuizen JF, Wagenvoort WA. 1974. Some aspects of seed germination in vegetables. I. The determination and application of heat sums and minimum temperature for germination. Scientiae Horticulturae 2:213-219.

Cardoso VJM. 2009. Uma análise termobiológica da germinação. Naturalia 32:35-52.

Cavalcante AMB, Perez SCJG A. 1995. Efeitos da temperatura sobre a germinação de sementes de Leucaena leucocephala (Lam.) de Wit. Revista Brasileira de Sementes 17:1-8.

Dau L, Labouriau LG. 1974. Temperature control of seed germination in Pereskia aculeata Mill. Anais da Academia Brasileira de Ciências 46:311-322.

Dionello SB. 1978. Germinação de sementes e desenvolvimento de plântulas de Kielmeyera coriaceae Mart. Tese de doutorado. Instituto de Biociências, Universidade de São Paulo, São Paulo.

Documenta Geigy. 1965. Tablas Científicas. Geigy S.A., Basel.

Egley GH. 1995. Seed germination in soil: dormancy cycles. In Seed development and germination (J Kiegel, G Galili, eds.). Marcel Dekker, New York, p.529-543.

Figueiredo SFL. 1989. Germinação de Simmondsia chinensis (Link) Schneider. Revista Brasileira de Fisiologia Vegetal 1:99-107.

Forsyth C, Staden JV. 1983. Germination of Tagetes minuta L. I - Temperature effects. Annals of Botany 52: 659-666.

Glasstone S, Laidler KJ, Eyring H. 1941. The theory of rate processes. McGraw-Hill, New York.

Harrington JF. 1962. The effect of temperature on the germination of several kinds of vegetable seeds. Proceedings of the XVI International Horticulture Congress, v.2, Bruxelles, p.435-441.

Hegarty TW. 1973. Temperature coefficient (Q10), seed germination and other biological processes. Nature 243:305-306. 
Hendricks SB, Taylorson RB. 1976. Variation in germination and amino acid leakage of seeds with temperature related to membrane phase change. Plant Physiology 58: 7-11.

Hendricks SB, Taylorson RB. 1979. Dependence of thermal responses of seeds on membrane transitions. Proceedings of the National Academy of Sciences of the United States of America 76:778-781.

Hiley GJP. 1981. Effects of high temperature on the germination of maize (Zea mays L.). Planta 151:68-74.

Joly CA, Felippe GM. 1979. Dormência das sementes de Rapanea guianensis Aubl. Revista Brasileira de Botânica 2:1-6.

Joly CA, Felippe GM, Dietrich SMC, Campos-Takaki GM. 1980. Physiology of germination and seed gel analysis in two populations of Magonia pubescens St. Hil. Revista Brasileira de Botânica 3:1-9.

Kotowsky F. 1926. Temperature relations to germination of vegetable seeds. Proceedings of the American Society for Horticultural Science 23:176-184.

Kramer PJ, Kozlowski TT. 1979. Physiology of trees. McGraw-Hill, New York.

Labouriau LG. 1970. On the physiology of seed germination in Vicia graminea $\mathrm{Sm}$ - I. Anais da Academia Brasileira de Ciências 42:235-262.

Labouriau LG. 1972. On the physiology of seed germination in Vicia graminea Sm. II - An analysis of the seed germination rate. Anais da Academia Brasileira de Ciências 44:477-534.

Labouriau LG. 1978. Seed germination as a thermobiological problem. Radiation and Environmental Biophysics 15:345-366.

Labouriau LG. 1983. A germinação das sementes. Secretaria Geral da O.E.A., Washington.

Labouriau LG, Agudo M. 1987. On the physiology of seed germination in Salvia hispanica L. I. Temperature effects. Anais da Academia Brasileira de Ciências 59:37-56.

Labouriau LG, Pacheco A. 1978. On the frequency of isothermal germination in seeds of Dolichos biflorus L. Plant and Cell Physiology 21:507-512.

Labouriau LG, Pacheco A. 1979. Isothermal germination rates of Dolichos biflorus L. Boletin de la Sociedad Venezolana de Ciencias Naturales 136:73-112.

Labouriau LG, Valadares MEB. 1976. On the germination of seeds of Calotropis procera (Ait.) Ait. F. Anais da Academia Brasileira de Ciências 48:263-284.

Melhem TS. 1975. Fisiologia da germinação das sementes de Dypterix alata Vog. (Leguminosae-Lotoideae). Hoehnea 5:59-90.
Nassif SML. 1996. Estudos referentes ao comportamento germinativo sob influência da disponibilidade hídrica, salinidade, luz, profundidade de plantio, substrato, temperatura e tratamentos para quebra de dormência. Dissertação de mestrado. Universidade Federal de São Carlos, São Carlos.

Perez SCJGA, Moraes JAPV. 1990. Influências da temperatura, da interação temperatura-giberelina e do estresse térmico na germinação de Prosopis juliflora (Sw.) D.C. Revista Brasileira de Fisiologia Vegetal 2:41-53

Perez SCJGA, Fanti SC, Casali CA. 1988. Temperature limits and thermal stress on seed germination of Peltophorum dubium Spreng Taubert. Revista Brasileira de Sementes 20:134-142.

Santos DL, Cardoso VJM. 2001. Thermal-biological aspects on the seed germination of Cucumis anguria L.: influence of he seed coat. Brazilian Journal of Botany 24:435-440.

Shannon CE. 1948. The mathematical theory of communication, University of Illinois Press, Urbana.

Snedecor GW. 1956. Statistical methods applied to experiments in Agriculture and Biology, Iowa State Coll. Press, Ames, Iowa.

Sokal RS, Rohlf FJ. 1969. Biometry, the principles and practice of statistics in biological research, W.H. Freeman, San Francisco.

Tambelini M, Perez SCJG de A. 1999. Physiological effects of temperature and thermal stress on the seed germination of Stryphnodendron polyphyllum Mart. Journal of Tropical Forestry Science 11:680-689.

Thompson PA. 1973. Geographical adaptation of seeds. In Seed ecology (W Heydecker, ed.). University Press / University Park, Pennsylvania, p.31-58.

Thompson PA, Fox DJC. 1976. The germination response of vegetable seeds in relation to their history of cultivation by man. Scientiae Horticulturae 4:1-14.

Vegis A. 1963. Climatic control of germination. In Environmental control of plant growth (L Evans, ed.). Academic Press, New York, p.265-288.

Whashitani I, Takenaka A. 1984. Germination responses of a non-dormant seed population of Amaranthus patulus Bertol. to constant temperatures in the sub-optimal range. Plant, Cell and Environment 7:353-358.

ZpevakFA. 1995. Efeitos do ácido abscísico, potencial hídrico, temperatura e tratamentos para quebra de dormência na germinação de sementes de Dimorphandra mollis Benth. Dissertação de mestrado, Universidade Federal de São Carlos, São Carlos. 